\title{
Lipolytic and proteolytic activity of Pseudomonas spp. isolated during milking and storage of refrigerated raw milk
}

\author{
Eduardo Capodifoglio, ${ }^{* 1}$ Ana Maria Centola Vidal, ${ }^{* 1}$ Joyce Aparecida Santos Lima, ${ }^{*}$ Fernanda Bortoletto,, \\ Léa Furlan D'Abreu, ${ }^{*}$ Ana Carolina Siqueira Gonçalves, ${ }^{*}$ Andreia Cristina Nakashima Vaz, \\ Julio Cesar de Carvalho Balieiro, $\dagger$ and Arlindo Saran Netto*2 \\ *School of Animal Science and Food Engineering, and \\ †School of Veterinary Medicine and Animal Science, University of Sao Paulo, Pirassununga 13635-900, Brazil
}

\begin{abstract}
The aim of this study was to verify the presence of lipolytic and proteolytic Pseudomonas spp. during milking and storage of refrigerated raw milk. We also intended to compare samples collected during rainy and dry seasons, from farms with manual and mechanical milking systems. For this, samples of milkers' hands, cows' teats, water, expansion tanks, equipment, and utensils used during milking were analyzed regarding Pseudomonas spp. count. Positive samples were tested for the production of lipolytic and proteolytic enzymes. Microorganisms of the genus Pseudomonas were isolated from all sampling points. A higher isolation rate of the bacterium was found in the rainy season except for 6 sampling points, with all of these associated with mechanical milking systems. Pseudomonas spp. exhibiting lipolytic activity were found to be predominant during the dry season, since no activity was detected during the rainy season in 26 of the 29 sampling sites. The highest number of lipolytic Pseudomonas isolates was obtained from water. Presence of lipase-producing Pseudomonas spp. was verified in 7 and $36 \%$ of the samples collected from farms with manual and mechanical milking, respectively. When analyzing raw milk collected from expansion tanks immediately $(0 \mathrm{~h})$ and $24 \mathrm{~h}$ after milking, we observed that for dairy properties with manual milking process, $10 \%$ of the Pseudomonas isolates were positive for lipolytic activity. The percentage increased to $12 \% 48 \mathrm{~h}$ after milking. Mean averages were 32,33 , and $39 \%$ immediately after, 24 and $48 \mathrm{~h}$ after milking, respectively, for farms with mechanical milking. All sampling points showed the presence of proteolytic strains of Pseudomonas. The highest proteolytic activity was found during the rainy season, except for the samples collected from milkers' hands before milking,
\end{abstract}

Received September 28, 2015.

Accepted February 26, 2016.

${ }^{1}$ These authors contributed equally to the study.

${ }^{2}$ Corresponding author: saranetto@usp.br buckets, and teat cup inner surfaces after milking and from the water in dairy farms with mechanical milking system. Of these samples, 72,56 , and $50 \%$, respectively, were positive for proteolysis during the dry season. For the water samples, a statistical difference was observed between mechanical (50\%) and manual (7\%) milking systems in the percentage of proteolytic activity. No production of proteolytic enzyme was detected in the samples from milkers' hands taken after milking and no statistically significant difference was found among manual (19.91\%) and mechanical (47.85\%) milking. During the rainy months, no proteolysis was detected in the samples taken from cows' teats after the predipping. It is evident, therefore, that preventive measures capable of minimizing the contamination with Pseudomonas spp. during milking and storage of refrigerated raw milk are needed, regardless of season.

Key words: milk, milking system, psychrotrophic, storage

\section{INTRODUCTION}

According to the USDA, in 2014, Brazil was the world's sixth largest milk producer behind the European Union, United States, India, China, and Russia (USDA, 2015). However, the bacteriological quality of the milk produced in Brazil is considered unsatisfactory and is a chronic problem that is difficult to solve. Problems related to the health of the mammary gland, hygiene during the milking process, effectiveness of cleaning practices, and raw milk storage conditions (Elmoslemany et al., 2009) are closely linked to the poor microbiological quality of the milk produced in the country.

From the expansion of the dairy sector in the country arose the necessity of prolonged storage of raw milk. However, with this also came the challenge of maintaining the quality of the products, preventing their deterioration and extending shelf life (Zeni et al., 2013).

Thus, in 2011, the Normative Instruction 62 (IN 62) was regulated by the Brazilian Ministry of Agriculture, 
Livestock and Supply. This states that refrigerated raw milk obtained from dairy farms must be stored in stainless-steel tanks at $4^{\circ} \mathrm{C}$ within less than $3 \mathrm{~h}$ after milking, remaining at this temperature for up to $48 \mathrm{~h}$ after the first milking (Brasil, 2011).

Cooling the milk immediately after milking aims to reduce multiplication of mesophilic bacteria that cause deterioration due to acidifying activity (Fagundes et al., 2006; Zeni et al., 2013). However, prolonged refrigerated storage at $4^{\circ} \mathrm{C}$ favors the development of psychrotrophic microorganisms, which, if present in feedstock, may cause alterations in milk and dairy products (Fagundes et al., 2006) due to the production of heat-resistant enzymes even after pasteurization and UHT treatment (Zeni et al., 2013). Thereby, proper management and hygiene practices during milking, storage, and transportation of refrigerated raw milk play a critical role in its bacteriological quality (Guerreiro et al., 2005).

Santos et al. (2009) found average temperatures of $14.5,5.5,5.2$, and $5.4^{\circ} \mathrm{C}$ after storing raw milk for 0,24 , 48 , and $72 \mathrm{~h}$, respectively. The authors concluded that the cooling temperature oscillates in dairy farms, which configures marginal refrigeration and provides favorable conditions for multiplication of psychrotrophic microorganisms (Santos and Laranja, 2001).

Psychrotrophic bacteria are defined as bacteria with high proliferation rates at low temperatures. Some strains of psychrotrophic microorganisms are known to have lipolytic and proteolytic ability (Cousin, 1982; Izidoro et al., 2013). Microorganisms of the genus Pseudomonas are classic psychrophiles, and according to Izidoro et al. (2013), have the highest metabolic activity, mostly lipolytic, in refrigerated milk $\left(4\right.$ to $\left.7^{\circ} \mathrm{C}\right)$.

Psychrotrophic microorganisms come from soil, water, air, dust, vegetation, and feces (Shah, 1994). Contact with the surface of the cooling tank, milking equipment, or utensils (or a combination of these) not properly cleaned and sanitized can contaminate the milk because these microorganisms easily multiply in milk residues found in containers, rubbers, joints, and any other location where accumulation of milk residues occurs (Guerreiro et al., 2005).

Even before the milking process, the teat skin of cows may be contaminated with psychrotrophic bacteria able to multiply at low temperatures and produce deteriorating enzymes, along with thermoduric microorganisms, which are resistant to pasteurization (Desmasures and Gueguen, 1997; Arcuri et al., 2008).

According to Forsythe (2002), bacteria of the genus Pseudomonas produce exopolysaccharides that contribute to biofilm formation and adhesion to surfaces of equipment and utensils used in the processing of milk and dairy products. Biofilms contain proteins, lipids, carbohydrates, minerals, and vitamins that form a crust under which bacteria continue to multiply, forming a pure culture or in association with other microorganisms that make them more resistant to the action of chemical and physical agents used for hygienization (Mosteller and Bishop, 1993; Parizzi, 1998; Nörnberg, 2009). Thus, when failures in hygiene procedures occur, residues adhere to equipment and surfaces become a potential source of contamination of milk (Nörnberg, 2009).

Lipolytic ability of Pseudomonas spp. depends on lipases secreted by these microorganisms that act mainly on the $\alpha$ portion of triglycerides (Castberg, 1992; Guerreiro et al., 2005), conferring a bitter taste and unpleasant aroma, characteristic of short-chain fatty acids, to the milk resulting in outright rejection of the milk by the dairy industry. The milk is then used by the cosmetics and soap industry (Nörnberg, 2009).

The proteolytic activity is carried out by the action of enzymes called heat-resistant proteases, naturally present in milk or produced by bacteria, particularly the psychrotrophic group, acting on $\kappa$-casein. On the other hand, whey proteins are more resistant to the action of these enzymes (Nörnberg et al., 2009). The k-casein hydrolysis causes destabilization of milk casein micelles and consequently coagulation and gel formation, making it impossible to consume the milk (Cousin, 1982; Shah, 1994).

In view of the production systems and agro-industrial chain of milk, it is of paramount importance to analyze the critical points that can lead to contamination with psychrotrophic, establishing a relationship between refrigeration, good manufacturing and hygiene practices during milking, storage, and transportation (Zeni et al., 2013).

The aim of this study was to verify the presence as well as the lipolytic and proteolytic activity of Pseudomonas spp. during milking by manual and mechanical means, and storage of refrigerated raw milk in rainy and dry seasons.

\section{MATERIALS AND METHODS}

Refrigerated raw milk samples were collected from 10 dairy farms belonging to the Rural Regional of the Development Office-EDR Limeira/SP. Five properties had mechanical milking with pipe closed circuit system and 5 had manual milking systems. All farms had expansion tanks. Samples were collected during the rainy season (between December 2013 and February 2014) and during the dry season (May to August 2014) at 3 different times for each property and season. During the study period, the average rainfall in the rainy and dry seasons was 85.20 and $21.85 \mathrm{~mm}$, respectively (USP, 2015). 
Samples of water used to clean the milking machines, equipment, and utensils, and the expansion tanks were collected. A pool of swabs was sampled from different sites during milking process: milkers' hands before and after milking, surface of the cows' teats before and after pre-dipping, inner surface of teat cups (mechanical milking) or bucket (manual milking) before and after milking, and inner surface of the expansion tank before milking.

The analyses were performed at the Animal Health and Food Security Multi-User Laboratory, School of Animal Science and Food Engineering, University of Sao Paulo.

Pseudomonas agar base (CM 559-Oxoid; Oxoid, Basingstoke, Hampshire, UK) with addition of supplement (CFC-SR103-Oxoid) was used for enumeration of Pseudomonas spp. (Cousin and Bramley, 1981). Serial decimal dilutions (up to $10^{-3}$ ) in $0.1 \%$ peptone water were prepared and 0.1-mL samples of appropriate dilutions were plated and then spread with a Drigalski handle. The plates were incubated at $28^{\circ} \mathrm{C}$ for $48 \mathrm{~h}$. Colonies were counted with a colony counter, and the total was multiplied by the plate dilution factor.

After counting, 3 to 5 colonies characteristic of Pseudomonas spp. were seeded in $5 \mathrm{~mL}$ of brain heart infusion broth and incubated at $35^{\circ} \mathrm{C}$ for $18 \mathrm{~h}$ (APHA, 1992). Then, $0.1 \mathrm{~mL}$ was plated on tributyrin agar (plate count agar supplemented with $1 \%$ tributyrin) and incubated at $28^{\circ} \mathrm{C}$ for $5 \mathrm{~d}$ to test for lipolytic activity (Beerens and Luquet, 1990).

To evaluate the proteolytic activity (Beerens and Luquet, 1990) of Pseudomonas spp., $0.1 \mathrm{~mL}$ of the inoculate was plated on milk agar (plate count agar supplemented with $1 \%$ skim milk powder) and then incubated at $28^{\circ} \mathrm{C}$ for 24 to $48 \mathrm{~h}$. In both tests performed, positivity was verified by the formation of a transparent halo around the colony.

A general linear model was used to examine the differences in Pseudomonas spp. proportions between different milking systems and period of year. As recommended by Banzatto and Kronka (2006), we used the scale of transformation "natural logarithm of the number of CFU + 1 (NL_CFU)" and then the ANOVA to assess the presence of Pseudomonas spp. Statistical analysis were carried out using the PROC MIXED procedure of the Statistical Analysis System version 9.1.3. (SAS Institute Inc., Cary, NC). The following model was adopted:

$$
\mathrm{Y}_{\mathrm{ijk}}=\mu+\mathrm{T}_{\mathrm{i}}+\mathrm{E}_{\mathrm{j}}+\mathrm{TE}_{\mathrm{ij}}+\mathrm{P}_{\mathrm{k}}+\mathrm{e}_{\mathrm{ijk}},
$$

where $\mathrm{Y}_{\mathrm{ijk}}=$ number of colony-forming units in transformed scale in farm k, season j, and milking system i; $\mu=$ constant inherent to all observations; $T_{i}=$ fixed effect of the ith milking system, where $\mathrm{i}=1$ (mechanical) or 2 (manual); $E_{j}=$ fixed effect of the jth season, where $\mathrm{j}=1$ (dry) or 2 (rainy); $\mathrm{P}_{\mathrm{k}}=$ random effect of the farm, supposed normally, independently identically distributed (NIID) $\left(0, \sigma_{p}^{2}\right) ; \mathrm{TE}_{\mathrm{ij}}=$ effect of double interaction existing between milking system i and season $\mathrm{j}$; and $\mathrm{e}_{\mathrm{ijk}}=$ residual random effect associated with the number of colony-forming units in transformed scale in farm $\mathrm{k}$, season $\mathrm{j}$, and milking system $\mathrm{i}$, supposed NIID $\left(0, \sigma_{p}^{2}\right)$.

Season effect was removed when Pseudomonas spp. were isolated in only one season of the year (dry or rainy).

A generalized linear model (assuming binomial distribution and logistic function) was used to assess the presence or absence of Pseudomonas spp. with lipolytic or proteolytic ability, according to the different milking systems and seasons. Data were analyzed using the PROC GLIMMIX procedure of the Statistical Analysis System version 9.1.3. (SAS Institute Inc.). The following model was adopted:

$$
\mathrm{Y}_{\mathrm{ijk}}=\eta(\mathrm{x})=\mu+\mathrm{T}_{\mathrm{i}}+\mathrm{E}_{\mathrm{j}}+\mathrm{TE}_{\mathrm{ij}}+\mathrm{P}_{\mathrm{k}}+\mathrm{e}_{\mathrm{ijk}},
$$

where $\mathrm{Y}_{\mathrm{ijkl}}=$ percentage of Pseudomonas isolates with lipolytic or proteolytic activity in farm $\mathrm{k}$, season $\mathrm{j}$, and milking system i; $\eta=$ logistic function relating the binomial variable with the systematic component of the model; $\mu=$ constant inherent to all observations; $\mathrm{T}_{\mathrm{i}}=$ fixed effect of the ith milking system, where $\mathrm{i}=1$ (mechanical) or 2 (manual); $E_{j}=$ fixed effect of the $j$ th season, where $\mathrm{j}=1$ (dry) or 2 (rainy); $\mathrm{P}_{\mathrm{k}}=$ random effect of the farm, supposed NIID $\left(0, \sigma_{p}^{2}\right) ; \mathrm{TE}_{\mathrm{ij}}=$ effect of double interaction existing between milking system i and season $\mathrm{j} ; \mathrm{e}_{\mathrm{ijk}}=$ residual random effect associated with farm $\mathrm{k}$, season $\mathrm{j}$, and milking system $\mathrm{i}$, supposed $\operatorname{NIID}\left(0, \sigma_{p}^{2}\right)$.

Season effect was removed when Pseudomonas spp. exhibiting lipolytic or proteolytic activity was detected in only one season of the year (dry or rainy).

\section{RESULTS AND DISCUSSION}

\section{Isolation and Enumeration of Pseudomonas spp.}

Table 1 shows the counts of Pseudomonas spp. during the rainy and dry seasons. In the rainy months, we found a minimum count of $1.09 \times 10^{1} \mathrm{cfu} \cdot \mathrm{mL}^{-1}$ in the water used in the milking parlor and a maximum count of $5.40 \times 10^{4} \mathrm{cfu} \cdot \mathrm{mL}^{-1}$ was detected on the surface of cows' teats after pre-dipping when manual milking was 
Table 1. Average counts of Pseudomonas spp. enumerated during milking according to the interactions between milking system (manual and mechanical) and season (rainy and dry) ${ }^{1}$

\begin{tabular}{|c|c|c|c|}
\hline Sampling site & $\begin{array}{l}\text { Milking } \\
\text { system }\end{array}$ & \multicolumn{2}{|c|}{ Pseudomonas spp. $\left(\mathrm{cfu} \cdot \mathrm{mL}^{-1}\right)$} \\
\hline \multirow[t]{2}{*}{ Water } & Manual & $1.92 \times 10^{2 \mathrm{~A}, \mathrm{a}}$ & $3.25 \times 10^{1 \mathrm{~A}, \mathrm{a}}$ \\
\hline & Mechanical & $1.09 \times 10^{1 \mathrm{~A}, \mathrm{a}}$ & $2.33 \times 10^{1 \mathrm{~A}, \mathrm{a}}$ \\
\hline \multirow[t]{2}{*}{ Milkers' hands before milking } & Manual & $8.44 \times 10^{2 \mathrm{~A}, \mathrm{a}}$ & $1.30 \times 10^{1 \mathrm{~B}, \mathrm{a}}$ \\
\hline & Mechanical & $1.19 \times 10^{2 \mathrm{~A}, \mathrm{a}}$ & $2.61 \times 10^{1 \mathrm{~A}, \mathrm{a}}$ \\
\hline Milkers' hands after milking & Manual & $2.48 \times 10^{3 \mathrm{~A}, \mathrm{a}}$ & $3.07 \times 10^{1 \mathrm{~B}, \mathrm{a}}$ \\
\hline & Mechanical & $1.19 \times 10^{2 \mathrm{~A}, \mathrm{~b}}$ & $4.11 \times 10^{2 \mathrm{~A}, \mathrm{a}}$ \\
\hline \multirow[t]{2}{*}{ Teat surface after pre-dipping } & Manual & $5.40 \times 10^{4 \mathrm{~A}, \mathrm{a}}$ & $1.97 \times 10^{1 \mathrm{~B}, \mathrm{a}}$ \\
\hline & Mechanical & $1.65 \times 10^{2 \mathrm{~A}, \mathrm{a}}$ & $1.11 \times 10^{3 \mathrm{~A}, \mathrm{a}}$ \\
\hline \multirow{2}{*}{ Bucket/teat cups inner surface before milking } & Manual & $5.86 \times 10^{3} \mathrm{~A}, \mathrm{a}$ & $3.84 \times 10^{1 \mathrm{~B}, \mathrm{~b}}$ \\
\hline & Mechanical & $1.22 \times 10^{3 \mathrm{~A}, \mathrm{a}}$ & $1.19 \times 10^{3 \mathrm{~A}, \mathrm{a}}$ \\
\hline \multirow{2}{*}{ Bucket/teat cups inner surface after milking } & Manual & $1.28 \times 10^{3 \mathrm{~A}, \mathrm{a}}$ & $1.70 \times 10^{1 \mathrm{~B}, \mathrm{~b}}$ \\
\hline & Mechanical & $3.67 \times 10^{2 \mathrm{~A}, \mathrm{a}}$ & $1.50 \times 10^{3} \mathrm{~A}, \mathrm{a}$ \\
\hline Milk can after milking & Manual & $6.05 \times 10^{3 \mathrm{~A}}$ & $1.03 \times 10^{4 \mathrm{~A}}$ \\
\hline
\end{tabular}

$\overline{\mathrm{A}, \mathrm{B} ; \mathrm{a}, \mathrm{b}}$ Values in the same row with different uppercase letters (dry season vs. rainy season) and the same column with different lowercase letters (mechanical milking vs. manual milking) were significantly different $(P<0.05)$.

${ }^{1}$ Samples were collected in farms belonging to the Rural Regional of the Development Office, EDR Limeira, SP, from December 2013 to August 2014.

performed. In the dry season, a minimum average count of $1.3 \times 10^{1} \mathrm{cfu} \cdot \mathrm{mL}^{-1}$ was observed in samples collected from milkers' hands before milking and maximum counts, found on milk cans after milking, averaged 1.03 $\times 10^{4} \mathrm{cfu} \cdot \mathrm{mL}^{-1}$.

Bacteria of the genus Pseudomonas were isolated from all sampling points, highlighting the need to intensify protective measures to minimize contamination by these microorganisms, which may cause various technological flaws in the dairy industry due to production of thermostable lipolytic and proteolytic enzymes.

Except for the samples collected from water $(2.33 \times$ $\left.10^{1} \mathrm{cfu} \cdot \mathrm{mL}^{-1}\right)$, teats before and after pre-dipping (4.11 $\times 10^{2} \mathrm{cfu} \cdot \mathrm{mL}^{-1}$ and $1.11 \times 10^{3} \mathrm{cfu} \cdot \mathrm{mL}^{-1}$, respectively), internal surface of teat cups and milk cans after milking $\left(1.50 \times 10^{3} \mathrm{cfu} \cdot \mathrm{mL}^{-1}\right.$ and $1.03 \times 10^{4} \mathrm{cfu} \cdot \mathrm{mL}^{-1}$, respectively), and from expansion tanks inner surface before milking $\left(8.50 \times 10^{3} \mathrm{cfu} \cdot \mathrm{mL}^{-1}\right)$, Pseudomonas spp. counts were higher during the rainy season $(P$ $<0.05$ ). All of these values mentioned above refer to samples collected from farms with a mechanical milking system and in the dry season. This indicates that Pseudomonas spp. are of environmental origin and grow in humid environments as stated by Costa et al. (1996), who reported the predilection of the Pseudomonadaceae family for aquatic habitats, wetlands, and areas with high rainfall. Silva et al. (2010) showed that during the rainy season, the herd health, water quality, hygiene conditions of the cattle stalls, milking equipment, and milkers' hands contributed decisively to the highest psychrotrophic count, especially Pseudomonas spp.

The water used in most of the properties where the samples were collected came from underground springs and did not receive any treatment before its utilization. Several authors highlight the importance of microbiological quality of water used in dairy farms, given that it comes into contact with all milking equipment and utensils and with milkers' hands before milking, favoring formation of biofilms and cross-contamination (Cousin and Bramley, 1981; Desmasures and Gueguen, 1997; Santana et al., 2001; Fagundes et al., 2006; Nörnberg, 2009).

Pseudomonas spp. levels in the water samples collected from farms with manual milking averaged $1.92 \times$ $10^{2} \mathrm{cfu} \cdot \mathrm{mL}^{-1}$ and $3.25 \times 10^{1} \mathrm{cfu} \cdot \mathrm{mL}^{-1}$ during the rainy and dry season, respectively, and $1.09 \times 10^{1} \mathrm{cfu} \cdot \mathrm{mL}^{-1}$ and $2.33 \times 10^{1} \mathrm{cfu} \cdot \mathrm{mL}^{-1}$ in properties with mechanical milking systems. Because no statistically significant difference was observed, we suggest that microbiological quality of water is similar between milking systems and seasons with respect to the count of Pseudomonas spp.

Fagundes et al. (2006) found mean counts of $1.49 \times$ $10^{4} \mathrm{cfu} \cdot \mathrm{mL}^{-1}$ in water used in farms with poor hygiene conditions. These results are much higher than those 
obtained by us (maximum count of $1.92 \times 10^{2} \mathrm{cfu} \cdot \mathrm{mL}^{-1}$ in water samples of farms with manual milking during rainy season).

Fagundes et al. (2006) also reported statistically significant differences in Pseudomonas spp. levels on the hands of milkers between farms with proper $(4.36 \times$ $\left.10^{3} \mathrm{cfu} \cdot \mathrm{mL}^{-1}\right)$ and poor $\left(6.26 \times 10^{3} \mathrm{cfu} \cdot \mathrm{mL}^{-1}\right)$ hygiene measures. However, in both cases, contamination with Pseudomonas spp. was considered high, highlighting the importance of efficient hygiene practices, regardless of the type of milk produced. In this study, we verified a higher contamination in milkers' hand samples collected before and after milking in farms with manual milking and in the rainy season, which may be explained by the fact that Pseudomonas spp. is an environmental contaminant (Shah, 1994). During the rainy season, the challenges with hygiene generally increase, especially in properties with manual milking systems in which the milker is in constant contact with the straps used for containment of animals and with the teat surface, representing a potential source of contamination for the milk.

No statistically significant difference in Pseudomonas spp. counts was noted between manual and mechanical milking during the dry season for the samples collected from milkers' hands before the milking process. However, a greater number of microorganisms was isolated in farms with mechanical milking systems during the dry season, probably due to contamination of the milking parlor water supply during the cleaning of the milking machines and cows' teats.

Upon comparing the dry and rainy season, the latter showed a statistically significantly higher level $(P<$ 0.05) of Pseudomonas spp. on the surface of the teats before $\left(1.08 \times 10^{4} \mathrm{cfu} \cdot \mathrm{mL}^{-1}\right)$ and after $\left(5.04 \times 10^{4}\right.$ $\mathrm{cfu} \cdot \mathrm{mL}^{-1}$ ) pre-dipping in farms with manual milking. Low-humidity environments pose a major challenge for growth and development of Pseudomonas spp. For the samples collected from the teats before pre-dipping in the rainy season, we also observed a statistical significant difference $(P<0.05)$ between milking systems (manual: $1.08 \times 10^{4} \mathrm{cfu} \cdot \mathrm{mL}^{-1}$ vs. mechanical: $1.19 \times 10^{2}$ $\left.\mathrm{cfu} \cdot \mathrm{mL}^{-1}\right)$. The generally poor hygiene during milking in farms with manual system, where only unchlorinated water was used to clean the teats, may justify these findings. In only 2 properties with mechanical milking, iodine solution was used to clean the teats, whereas in the others pre-dipping was done with unchlorinated water. This may explain the increase in the count of Pseudomonas spp. on cows' teats after pre-dipping compared with samples taken before pre-dipping in farms with mechanical milking during the dry season.

In this study, pre-dipping was not effective for the control of bacteria of the genus Pseudomonas in the farms surveyed. However, according to Oliveira et al. (2010), pre-dipping helps to prevent the contamination of milking equipment by environmental microorganisms. Fernandes et al. (2009) noted the presence of Pseudomonas spp. in the pre-dipping solution, thus demonstrating the transmission of these microorganisms among cows. The authors affirmed that Pseudomonas spp. contamination increased after the use of pre-dipping in the dairy farms assessed, showing that commercial iodine solution (4 ppm) is not efficient in eliminating Pseudomonas spp.

Although not statistically significant, in the rainy season, the initial count of Pseudomonas spp. was higher in samples from the bucket surface compared with the teat cups both before and after milking. A reversed statistically significant relationship was observed during dry months $(P<0.05$, Table 1$)$. According to Guerreiro et al. (2005), presence of residual milk in the milking unit is favorable to growth and development of these bacteria. Fagundes et al. (2006) reported an increased presence of Pseudomonas spp. in dairy farms with poor hygiene standards. This may be related to inadequate practices in cleaning and sanitizing of surfaces/equipment. Santana et al. (2001) found that using hot water $\left(100^{\circ} \mathrm{C}\right)$ in the cleaning process of teat cups is beneficial in reducing the initial contamination with mesophilic and psychrotrophic microorganisms.

Improper cleaning practices after milk collection by bulk tanker could also explain the contamination of the inner surface of expansion tanks. When not removed in the cleaning process, microorganisms attach to the surface of milking equipment and utensils favoring the formation of biofilms, which are resistant to sanitization and may serve as a continuous contamination source (Figueiredo et al., 2009).

No statistically significant difference in the count of Pseudomonas spp. was observed for samples collected from sieves and milk cans before and after milking. Mean averages of Pseudomonas spp. for the sieve surface before milking were $1.79 \times 10^{3}$ and $7.27 \times 10^{2}$ $\mathrm{cfu} \cdot \mathrm{mL}^{-1}$ in the rainy and dry season, respectively. As for samples collected after milking, Pseudomonas spp. counts averaged $5.99 \times 10^{3}$ and $5.78 \times 10^{2} \mathrm{cfu} \cdot \mathrm{mL}^{-1}$. For samples taken from milk cans before and after milking, average Pseudomonas spp. counts were of $12 \times$ $10^{3}$ and $6.05 \times 10^{3} \mathrm{cfu} \cdot \mathrm{mL}^{-1}$, respectively, in the rainy season, and $1.17 \times 10^{3}$ and $1.03 \times 10^{4} \mathrm{cfu} \cdot \mathrm{mL}^{-1}$ during the dry season. In all cases, values were considered elevated, thus contributing to further contamination of milk. Once again, the need for preventive measures capable of controlling Pseudomonas spp. load on milking machines and utensils was highlighted.

The milk from the expansion tank was sampled at 0,24 , and $48 \mathrm{~h}$ after the mechanical milking, and at 0 , 
Table 2. Average counts of Pseudomonas spp. enumerated during storage of refrigerated raw milk according to the interactions between milking system (manual and mechanical) and season (rainy and dry) ${ }^{1}$

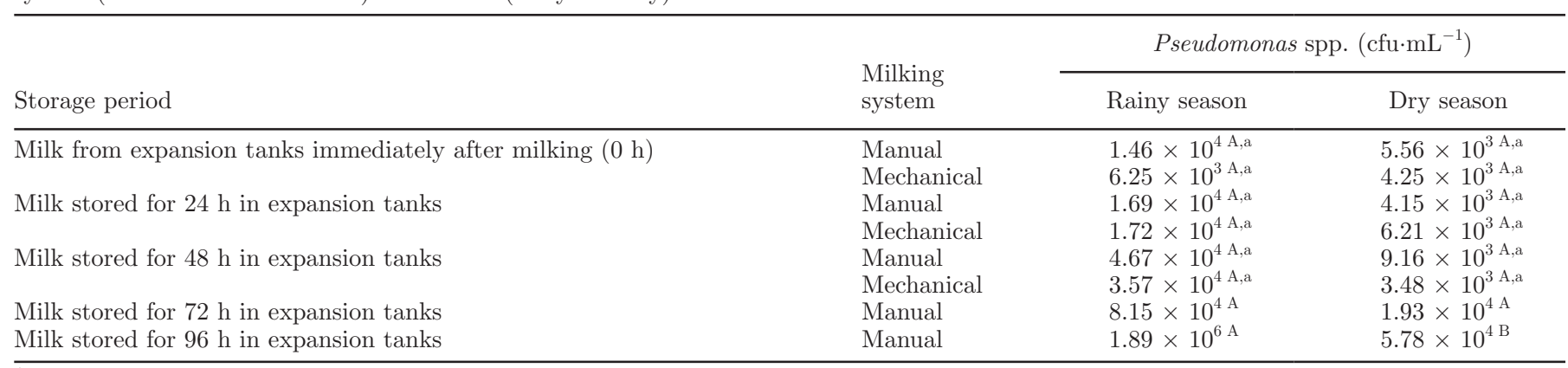

$\overline{\mathrm{A}, \mathrm{B} ; \mathrm{a}}$ Values in the same row with different uppercase letters and the same column with different lowercase letters were significantly different $(P$ $<0.05)$.

${ }^{1}$ Samples were collected in farms belonging to the Rural Regional of the Development Office, EDR Limeira, SP, from December 2013 to August 2014 .

$24,48,72$, and $96 \mathrm{~h}$ after manual milking. At all times, milk samples from expansion tanks were held at $4^{\circ} \mathrm{C}$. Levels of Pseudomonas spp. enumerated during storage of refrigerated raw milk in the rainy and dry season are summarized in Table 2. During the rainy months, the minimum isolation level of Pseudomonas spp. $(6.25 \times$ $10^{3} \mathrm{cfu} \cdot \mathrm{mL}^{-1}$ ) was found in milk stored immediately after milking $(0 \mathrm{~h})$ and the maximum averages (1.89 $\left.\times 10^{6} \mathrm{cfu} \cdot \mathrm{mL}^{-1}\right)$, after storing for $96 \mathrm{~h}$. In the dry season, the minimum counts $\left(3.48 \times 10^{3} \mathrm{cfu} \cdot \mathrm{mL}^{-1}\right)$ were observed in the refrigerated raw milk after $48 \mathrm{~h}$, and maximum $\left(5.78 \times 10^{4} \mathrm{cfu} \cdot \mathrm{mL}^{-1}\right)$, after $96 \mathrm{~h}$.

For samples collected in dairy farms with manual milking system, initial levels of Pseudomonas spp. at 0 $\mathrm{h}$ were $1.46 \times 10^{4}$ and $5.56 \times 10^{3} \mathrm{cfu} \cdot \mathrm{mL}^{-1}$ in the rainy and dry season, respectively. In farms with mechanical milking, the initial level was $6.25 \times 10^{3}$ and $4.25 \times 10^{3}$ $\mathrm{cfu} \cdot \mathrm{mL}^{-1}$ at the same period. High initial counts are a strong indicator of lack of good hygiene practices. According to Cousin and Bramley (1981), the presence of feces, mud, and bedding material on the surface of cows' teats not cleaned properly is a major risk factor for the contamination of milk.

We noted an increase in the counts of Pseudomonas spp. during storage of milk. The same pattern was reported by Muir (1996), Ryser (1999), Santos and Laranja (2001), and Fagundes et al. (2006). However, no statistically significant difference was found between milking procedures until storage for $48 \mathrm{~h}$, when the milk from dairy farms with mechanical milking was transported to milk processing plants. We found much higher counts of Pseudomonas spp. in milk stored for $96 \mathrm{~h}$ in expansion tanks during the rainy season compared with the dry season $(P<0.05)$. This shows that is crucial for the dairy companies to collect the milk within $48 \mathrm{~h}$ after milking, thus avoiding the high multiplication of Pseudomonas spp., which can cause alterations in milk composition and other characteristics.

Our results agree with the findings of Guerreiro et al. (2005) who concluded that the technology level of milking procedure does not necessarily imply milk with better microbiological quality. The researchers found higher initial counts of psychrotrophic bacteria in farms with mechanical milking systems than in properties with rudimentary manual milking. This is justified because milking machines become potential sources of milk contamination when improperly sanitized (Guerreiro et al., 2005).

\section{Lipolytic Activity}

Data presented in Tables 3 and 4 illustrate the comparison between the 2 different milking systems (manual and mechanical) in the dry season. Of all isolates tested in this study, no lipase activity was detected in 26 of the 29 sampling sites during the rainy season. In farms with manual milking, lipolytic Pseudomonas spp. was isolated after milking in samples of the bucket's inner surface $(7.6 \%$ of total samples), milk from the expansion tank (6.6\% of total samples), and milk cans ( $7.6 \%$ of total samples). For dairy properties with a mechanical milking system, the presence of lipolytic Pseudomonas spp. was not documented during the rainy months.

The results observed for the lipolytic enzymes produced by bacteria of the genus Pseudomonas in the dry season disagree with what is generally seen in other studies, because the bacterium belonging to the Pseudomonadaceae family is often associated with aquatic environments, wetlands, and high rainfall (Costa et al., 1996). Similar results were obtained by Moreira and Montanhini (2014). These authors reported lipolytic activity in $44.1 \%$ of total milk samples analyzed, whereas proteolytic activity was detected in only $11 \%$. 
Table 3. Percentage of samples collected in different sampling sites during the dry season positive for lipolytic Pseudomonas spp.

\begin{tabular}{llc}
\hline Sampling site & $\begin{array}{l}\text { Milking } \\
\text { system }\end{array}$ & $\begin{array}{c}\text { \% of samples positive for lipase } \\
\text { positive Pseudomonas spp. }\end{array}$ \\
\hline Water & Manual & $7^{\mathrm{b}}$ \\
Milkers' hands before milking & Mechanical & $36^{\mathrm{a}}$ \\
Milkers' hands after milking & Manual & $21^{\mathrm{a}}$ \\
Teat surface before milking & Mechanical & $24^{\mathrm{a}}$ \\
& Manual & $12^{\mathrm{a}}$ \\
Bucket/teat cups inner surface before milking & Mechanical & $24^{\mathrm{a}}$ \\
Bucket/teat cups inner surface after milking & Manual & $10^{\mathrm{a}}$ \\
& Mechanical & $16^{\mathrm{a}}$ \\
Expansion tank inner surface before milking & Mechananical & $13^{\mathrm{a}}$ \\
& Manual & $32^{\mathrm{a}}$ \\
& Mechanical & $10^{\mathrm{a}}$ \\
\hline
\end{tabular}

${ }^{a, b}$ Values in the same column with different lowercase letters were significantly different $(P<0.05)$.

In this study, the highest percentage of lipolytic Pseudomonas spp. was observed in the water samples. Presence of lipase-producing Pseudomonas spp. was verified in 7 and $36 \%$ of the samples collected from farms with manual and mechanical milking, respectively. We also observed that the proportion of lipolytic Pseudomonas spp. in milk increased according to the storage period. For dairy properties with a manual milking process, $10 \%$ of the samples analyzed immediately $(0 \mathrm{~h})$ and $24 \mathrm{~h}$ after milking were positive for lipolytic activity. The percentage increased to $12 \% 48 \mathrm{~h}$ after milking. Mean averages were 32, 33, and 39\% immediately after, and 24 and $48 \mathrm{~h}$ after milking, respectively, for farms with mechanical milking, thereby demonstrating that storage time is inversely proportional to milk quality.

These results could be explained by the fact that in production systems using mechanical milking, cows are generally milked at least twice a day. This practice leads to oscillation of milk temperature, favoring the growth of psychrotrophic Pseudomonas spp. and enzyme production by these microorganisms, as reported by Santos and Laranja (2001).

According to Arcuri et al. (2008), lipolytic Pseudomonas spp. percentages were higher at $7^{\circ} \mathrm{C}(90.9 \%$ of total samples), $10^{\circ} \mathrm{C}$, and $21^{\circ} \mathrm{C}$ (both $81.81 \%$ of total samples), and Pseudomonas fluorescens showed lipolytic ability in $100 \%$ of the isolates tested at $4,7,10$, and $21^{\circ} \mathrm{C}$. In this work, percentages of lipolytic Pseudomonas spp. were lower when compared with those found by Arcuri et al. (2008), which may be due to the differences in milk storage temperatures. Besides this, not all Pseudomonas strains are equally capable of producing lipases with the same efficiency (Hantsis-Zacharov and Halpern, 2007).

Thus, it is evident that duration of the storage period in refrigerated tanks, especially at marginal temperatures $\left(5\right.$ to $\left.10^{\circ} \mathrm{C}\right)$, favors microbial multiplication and possible lipolysis action of lipases in the milk, causing its deterioration (Santos and Laranja, 2001).

\section{Proteolytic Activity}

The percentage of proteolytic activity of Pseudomonas spp. isolated from different sampling points during milking and storage of raw milk is shown in Table 5. For the dairy farms with a mechanical milking system, the highest proportion of proteolytic Pseudomonas spp. was associated with the rainy season. However, for the samples taken from the milkers' hands before milking, the inner surface of the buckets and teat cups

Table 4. Percentage of samples positive for lipolytic Pseudomonas spp. during storage of refrigerated raw milk in the dry season

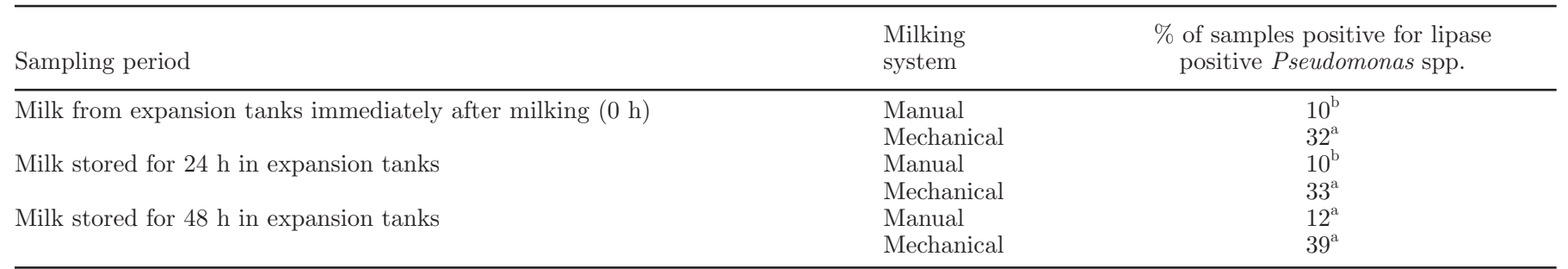

\footnotetext{
${ }^{\mathrm{a}, \mathrm{b}}$ Values in the same column with different lowercase letters were significantly different $(P<0.05)$.
} 
Table 5. Percentage of samples collected in different sampling sites during milking positive for proteolytic Pseudomonas spp., according to milking system (manual and mechanical) and season (rainy and dry)

\begin{tabular}{|c|c|c|c|}
\hline \multirow[b]{2}{*}{ Sampling site } & \multirow{2}{*}{$\begin{array}{l}\text { Milking } \\
\text { system }\end{array}$} & \multicolumn{2}{|c|}{$\begin{array}{l}\% \text { of samples positive for protease } \\
\text { positive Pseudomonas spp. }\end{array}$} \\
\hline & & Rainy season & Dry season \\
\hline$\overline{\text { Water }}$ & $\begin{array}{l}\text { Manual } \\
\text { Mechanical }\end{array}$ & $\begin{array}{l}27^{\mathrm{A}, \mathrm{a}} \\
33^{\mathrm{A}, \mathrm{a}}\end{array}$ & $\begin{array}{r}7^{\mathrm{A}, \mathrm{b}} \\
50^{\mathrm{A}, \mathrm{a}}\end{array}$ \\
\hline Milkers' hands before milking & $\begin{array}{l}\text { Manual } \\
\text { Mechanical }\end{array}$ & $\begin{array}{l}43^{\mathrm{A}, \mathrm{a}} \\
51^{\mathrm{A}, \mathrm{a}}\end{array}$ & $\begin{array}{l}19^{\mathrm{A}, \mathrm{a}} \\
72^{\mathrm{A}, \mathrm{a}}\end{array}$ \\
\hline Milkers' hands after milking & $\begin{array}{l}\text { Manual } \\
\text { Mechanical }\end{array}$ & $\begin{array}{l}19.91^{\mathrm{a}} \\
47.85^{\mathrm{a}}\end{array}$ & -1 \\
\hline Teat surface before pre-dipping & $\begin{array}{l}\text { Manual } \\
\text { Mechanical }\end{array}$ & $\begin{array}{l}40^{\mathrm{A}, \mathrm{a}} \\
14^{\mathrm{A}, \mathrm{a}}\end{array}$ & $\begin{array}{r}6^{\mathrm{B}, \mathrm{a}} \\
18^{\mathrm{A}, \mathrm{a}}\end{array}$ \\
\hline Teat surface after pre-dipping & $\begin{array}{l}\text { Manual } \\
\text { Mechanical }\end{array}$ & - & $\begin{array}{l}24.16^{\mathrm{a}} \\
34.34^{\mathrm{a}}\end{array}$ \\
\hline Bucket/teat cups inner surface before milking & $\begin{array}{l}\text { Manual } \\
\text { Mechanical }\end{array}$ & $\begin{array}{l}46^{\mathrm{A}, \mathrm{a}} \\
33^{\mathrm{A}, \mathrm{a}}\end{array}$ & $20^{\mathrm{A}, \mathrm{a}}$ \\
\hline Bucket/teat cups inner surface after milking & $\begin{array}{l}\text { Manual } \\
\text { Mechanical }\end{array}$ & $\begin{array}{l}71^{\mathrm{A}, \mathrm{a}} \\
23^{\mathrm{A}, \mathrm{a}}\end{array}$ & $\begin{array}{r}6^{\mathrm{B}, \mathrm{a}} \\
56^{\mathrm{A}, \mathrm{a}}\end{array}$ \\
\hline Expansion tank inner surface before milking & $\begin{array}{l}\text { Manual } \\
\text { Mechanical }\end{array}$ & $\begin{array}{l}33^{\mathrm{A}, \mathrm{a}} \\
67^{\mathrm{A}, \mathrm{a}}\end{array}$ & $\begin{array}{l}23^{\mathrm{A}, \mathrm{a}} \\
29^{\mathrm{B}, \mathrm{a}}\end{array}$ \\
\hline
\end{tabular}

after milking and from the water, higher percentages of Pseudomonas spp. exhibiting proteolytic activity were found during the dry period. Of these, 72,56 , and $50 \%$, respectively, were considered positive.

From all sampling sites, we successfully isolated proteolytic Pseudomonas spp., highlighting the need for control measures against these microorganisms. A higher percentage of proteolytic Pseudomonas spp. was obtained from water samples collected during the dry season in farms with mechanical milking $(50 \%)$ when compared with the manual system (7\%), differing statistically from each other $(P<0.05)$. These results show the importance of treating the water used in dairy farms (e.g., by chlorination), because the microbiological quality of the water affects the entire milking system and consequently the quality of the milk produced.

No statistical difference was observed for proteolytic Pseudomonas strains between milking systems and seasons for samples collected from milkers' hands before milking. Yet, $72 \%$ of isolates collected in dairy farms with mechanical milking and during the dry season were found positive for proteolytic activity, representing a risk for milk quality. In the work of Moreira and Montanhini (2014), proteolytic activity was detected in only $6.67 \%$ of samples. In view of the results, we can state that appropriate hand and arm hygiene of workers is a critical point for the control of the spread of this bacterium among animals. This highlights the need for health education assistance programs for milk producers seeking to improve the quality of milk and dairy products (Moreira and Montanhini, 2014). In the present study, the milkers had the habit of washing hands before the start of milking in only one of the 10 farms evaluated.

No proteolytic enzyme was produced by isolates sampled from milkers' hands after milking in dry season and also no statistically significant difference between manual (19.91\%) and mechanical (47.85\%) milking was observed. The percentage of proteolytic Pseudomonas spp. isolated from the surface of cows' teats in farms with manual milking was significantly lower $(P<0.05)$ during the dry season (6\%) in contrast to the rainy season (40\%). This can be explained by cows' habit of lying down during the interval between milkings, which favors contamination of the skin of the teats and udder (Moreira and Montanhini, 2014).

No production of protease was observed in samples taken from teats after pre-dipping, which may be due to the antibacterial effect of the pre-dipping solution against Pseudomonas spp. However, the physiological mechanism of these bacteria and under which conditions the gene responsible for production of proteases is expressed remain to be elucidated.

We found relatively high percentages of proteolytic Pseudomonas spp. in samples from the inner surface of the buckets and teat cups collected before and after milking, and from the inner surface of the expansion tank taken before milking in the rainy period. This suggests that hygiene failures, involving incorrect temperature conditions and inadequate sanitizer concentration or delays in exchanges of the teat cups rubbers (Costa, 2006; Moreira and Montanhini, 2014), favor biofilm 
Table 6. Percentage of samples collected during storage of refrigerated raw milk positive for proteolytic Pseudomonas spp., according to milking system (manual and mechanical) and season (rainy and dry)

\begin{tabular}{|c|c|c|c|}
\hline \multirow[b]{2}{*}{ Storage period } & \multirow{2}{*}{$\begin{array}{l}\text { Milking } \\
\text { system }\end{array}$} & \multicolumn{2}{|c|}{$\begin{array}{l}\% \text { of samples positive for protease } \\
\text { positive Pseudomonas spp. }\end{array}$} \\
\hline & & Rainy season & Dry season \\
\hline
\end{tabular}

\footnotetext{
${ }^{\mathrm{A}, \mathrm{a}}$ Values in the same row with different uppercase letters and the same column with different lowercase letters were significantly different $(P$
} $<0.05)$.

formation. According to Teh et al. (2012), bacterial attachment to stainless steel apparently increases proteolysis. When analyzing biofilms, the authors reported that Pseudomonas fluorescens can produce proteases at 20, 30, and $37^{\circ} \mathrm{C}$ (Teh et al., 2012).

Percentages of proteolytic Pseudomonas spp. isolated from refrigerated raw milk samples stored in expansion tanks are listed in Table 6 . The highest proportions were found in the rainy season and proteolysis was detected in $45 \%$ of the samples collected $48 \mathrm{~h}$ after milking in farms with mechanical milking systems. Samples collected from the tank $48 \mathrm{~h}$ after manual milking in the dry months had the lowest percentage of proteolytic Pseudomonas spp., only $16 \%$.

Although no statistically significant difference was present between milk stored in tanks for 0 or $48 \mathrm{~h}$, mechanical milking posed a greater risk of contamination with proteolytic Pseudomonas spp. compared with manual milking.

In a prior study, Moreira and Montanhini (2014) found the highest percent of proteolytic Pseudomonas spp. in a farm where, although water was treated with chlorine, the first 3 milk jets were not discarded. Workers did not have the habit of discarding the first 3 milk jets in any of the farms evaluated (mechanical milking system). In the dairy properties with manual milking, the corresponding volume of milk was consumed by the calf. Nero et al. (2009) emphasize that discarding the first milk jets is an important hygienic measure because this prevents milk contamination by microorganisms present on the udder and teat surface. This is crucial because milk is stored at temperatures ideal for the development of psychrotrophic microorganisms, which can cause severe alterations in milk quality.

\section{CONCLUSIONS}

Bacteria of the genus Pseudomonas were isolated throughout the milking process and storage of refrigerated raw milk in dairy farms with mechanical and manual milking systems and during the rainy and dry season. We concluded that these microorganisms are of environmental origin and indicate deficient hygiene during milking and failures during storage of raw milk. We also verified the lipolytic activity (mainly in the dry season) and proteolytic activity (mainly during the rainy season) of these microorganisms.

\section{ACKNOWLEDGMENTS}

The authors acknowledge the Sao Paulo Research Foundation (FAPESP, Sao Paulo, Brazil) for the research funding (FAPESP Process 2013/04131-2).

\section{REFERENCES}

APHA (American Public Health Association). 1992. Compendium of methods for the microbiological examination of foods. 2nd ed. APHA, Washington, DC.

Arcuri, E. F., P. D. L. Silva, M. A. V. P. Brito, J. R. F. Brito, C. C. Lange, and M. M. A. Magalhães. 2008. Count, isolation and characterization of psychrotrophic bacteria from refrigerated raw milk. Cienc. Rural. 38:2250-2255.

Banzatto, D. A., and S. N. Kronka. 2006. Agricultural Experimentation. FUNEP, Jaboticabal/SP, Brazil.

Beerens, H., and F. M. Luquet. 1990. Practical guide for microbiological analysis of milk and dairy products. Acribia Editorial Acríbia S.A., Zaragoza, Spain.

Brasil. 2011. Ministry of Agriculture, Livestock and Supply. DIPOA. Normative Instruction No. 62 of 29 Dec. 2011. Diário Oficial da União. Brasília.

Castberg, H. G. 1992. Lipase activity. Int. Dairy Fed. Bulletin. 271:18 20.

Costa, E. O., A. R. Ribeiro, F. G. Junior, J. A. B. Silva, and R. B. Pardo. 1996. Bovine mastitis due to environmental agents: Pseudomonas sp.; Plesiomonas sp.; Proteca sp. Semina: Ci. Agrárias. 17:22-25.

Costa, F. F. 2006. Management practices interference on the microbiological quality of the milk produced in family farms. MS Thesis. Sao Paulo State "Júlio de Mesquita Filho", Jaboticabal, Brazil.

Cousin, M. A. 1982. Presence and activity of psychrotrophic microrganisms in milk and dairy products: A review. J. Food Prot. $45: 172-207$.

Cousin, M. A., and A. J. Bramley. 1981. The microbiology of raw milk. Pages 119-163 in Dairy Microbiology of Milk. Vol. 1. R. K. Robinson, ed. Applied Science Publishers, London, UK.

Desmasures, N., and M. Gueguen. 1997. Monitoring the microbiology of high quality milk by monthly sampling over 2 years. J. Dairy Res. 64:271-280.

Elmoslemany, A. M., G. P. Keefe, I. R. Dohoo, and B. M. Jayarao. 2009. Risk factors for bacteriological quality of bulk tank milk in 
Prince Edward Island dairy herds. Part 1: Overall risk factors. J. Dairy Sci. 92:2634-2643.

Fagundes, C. M., V. Fischer, W. P. da Silva, N. Carbonera, and M. R. Araújo. 2006. Presence of Pseudomonas spp. related to different phases of the milking process with different hygienic managements and in refrigerated milk. Cienc. Rural. 36:568-572.

Fernandes, M. C., M. G. Ribeiro, A. K. Siqueira, T. Salerno, G. H. B. Lara, and F. J. P. Listoni. 2009. Outbreak of bovine mastitis caused my multiple drug resistant Pseudomonas aeruginosa strains. Arq. Bras. Med. Vet. Zootec. 61:745-748.

Figueiredo, H. M., N. J. Andrade, E. F. Ozela, and G. P. Morales. 2009. The speed of milk circulation influences the adhesion of Pseudomonas aeruginosa on stainless steel. Ciênc. Tecnol. Aliment. 29:469-473.

Forsythe, S. J. 2002. Food Safety Microbiology. Artmed, Porto Alegre, RS, Brazil.

Guerreiro, P. K., M. R. F. Machado, G. C. Braga, E. Gasparino, and A. S. M. Franzener. 2005. Microbiological quality of milk through preventive techniques in the handling of production. Ciênc. Agrotec. 29:216-222.

Hantsis-Zacharov, E., and M. Halpern. 2007. Culturable psychrotrophic bacterial communities in raw milk and their proteolytic and lipolytic traits. Appl. Environ. Microbiol. 73:7162-7168.

Izidoro, T. B., J. G. Pereira, V. M. Soares, T. L. B. Spina, and J. P. A. N. Pinto. 2013. Proteolytic activity of psychotropic bacteria in milk stored at different temperatures. Rev. Ceres. 60:452-457.

Moreira, N. V., and M. T. M. Montanhini. 2014. Milk contamination in the milking by proteolytic and lipolytic microorganisms. Rev. Bras. Hig. San. Anim. 08:29-38.

Mosteller, T. M., and J. R. Bishop. 1993. Sanitizer efficacy against attached bacteria in a milk biofilm. J. Food Prot. 56:34-41.

Muir, D. D. 1996. The shelf-life of dairy products: Factors influencing raw and fresh products. J. Soc. Dairy Technol. 49:24-32.

Nero, L. A., G. N. Viçosa, and F. E. V. Pereira. 2009. Microbiological quality of the milk determined by the product characteristics. Ciênci. Tecnol. Aliment. 29:386-390.

Nörnberg, M. F. B. L. 2009. Proteolytic activity, biofilm adhesion and production by psychrotrophic microorganisms in bovine milk Accessed Jul. 29, 2015. http://www.lume.ufrgs.br/bitstream/ handle/10183/16148/000697839.pdf?Sequence=1.
Nörnberg, M. F. B. L., E. C. Tondo, and A. Brandelli. 2009. Psychrotrophic bacteria and proteolytic activity in refrigerated raw milk. Acta Sci. Vet. 37:157-163.

Oliveira, U. V., G. S. Galvão, A. R. R. Paixão, and A. D. Munhoz. 2010. Occurrence, infectious etiology and risk factors for bovine mastitis in the microregion of Itabuna - Ilheus, Bahia. Rev. Bras. Saúde. Prod. Anim. 11:630-640.

Parizzi, S. Q. F. 1998. Bacterial adherence in hospital food services surfaces assessed by epifluorescence microscopy. MS Thesis. Viçosa Federal Univ., Viçosa.

Ryser, E. 1999. Microorganisms of importance in raw milk. Michigan Dairy Review. 8:7-9.

Santana, E. H. W. V. Beloti, M. A. F. Barros, L. B. Moraes, V. V. Gusmão, and M. S. Pereira. 2001. Milk contamination in different parts of the production process: I. Aerobic mesophilic and psychrotrophic microorganisms. Semina: Ci. Agrárias. 22:145-154.

Santos, M. V., and F. L. F. Laranja. 2001. Importance and effect of psychotropic bacteria on milk quality. Hig. Aliment. 15:13-19.

Santos, P. A., M. A. P. Dilva, P. I. B. Anastácio, H. A. S. Junior, J. W. Silva, and E. S. Nicolau. 2009. Assessment of the storage time on refrigerated raw milk quality parameters. Rev. Inst. Latic. Cândido Tostes 64:35-41.

Shah, N. P. 1994. Psychrotroph in milk: A review. Milchwissenschaft 49:432-437.

Silva, M. A. P., P. A. Santos, J. W. Silva, K. M. Leão, A. N. Oliveira, and E. S. Nicolau. 2010. Change in the quality of cooled raw milk due to the year period and type of milking. Rev. Inst. Adolfo Lutz 69:112-118.

Teh, K. H., S. Flint, J. Palmer, P. Andrewes, P. Bremer, and D. Lindsay. 2012. Proteolysis produced within biofilms of bacterial isolates from raw milk tankers. Int. J. Food Microbiol. 157:28-34.

USDA. 2015. USDA Foreign Agricultural Service. Accessed Feb. 23, 2015. http://apps.fas.usda.gov/psdonline/.

USP. 2015. University of Sao Paulo - Campus Pirassununga. Weather Station. Accessed Aug. 23, 2015. ftp://ftp.cisc.usp.br/pub/ PCAPS/estacao.html.

Zeni, M. P., M. H. S. Maran, G. P. R. Silva, E. M. Carli, and S. C. Palezi. 2013. Influence of psychotropic microorganisms on the quality of refrigerated milk to UHT production. Unoesc \& Ci. ACET 4:61-70. 